\title{
The Effect of Some Coating Materials on the amount of Leaching Monomer from \\ Poly Methyl Methacrylate Denture Base
}

\author{
Nadia T Jaffer \\ BDS, MSc (Assist. Lect)
}

Monia MN Kandil

BDS, MSc (Assist. Lect)

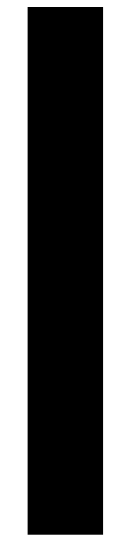

\author{
Department of Prosthetic Dentistry \\ College of Dentistry, University of Mosul
}

\begin{abstract}
Aims: to evaluate the effect of three coating materials on the amount of residual monomer leaching from acrylic resin denture base. Materials and methods: twenty specimens of a heat-cured acrylic resin denture base were prepared at dimensions of $30 \times 10 \times 1.5 \mathrm{~mm}$ length, width and thickness; respectively. These specimens were divided into four groups: control (in which the denture base left uncoated), monopoly coated, grape seeds oil coated and olive oil coated groups. For monomer leaching analysis, each specimen was put in a glass tube containing $10 \mathrm{ml}$ of deionized water that was changed daily. Monomer levels were measured by spectrophotometer at $254 \mathrm{~nm}$, every 24 hour for 7 days analytic period. The results were expressed as a percentage of leached monomer mass with respect to the weight of specimen. Results: statistical analysis showed that there was a significant difference in the percentage of residual monomer leaching in uncoated and monopoly coated groups; and insignificant difference in grape and olive oils coated groups. However, there was a daily decrease in monomer leaching for all groups. Grape and olive oils coated groups, showed lower leached residual monomer during the whole experimental period than the uncoated and monopoly coated specimens, the daily reduction of monomer leaching was sharp in the uncoated (control) and monopoly coated groups, and it was gradual and slow in oils coated groups. Conclusions: the using of natural oils (grape and olive oils), was more beneficial in reduction of residual monomer leaching, than the resin coating materials (monopoly) in comparison to uncoated acrylic resin denture base. Key words: Acrylic resin denture base, monomer leaching, coating materials, monopoly, natural oils.

Key wards: oral, oropharyngeal, cancer, Mosul.

Jaffer NT, Kandil MMN. The Effect of Some Coating Materials on the amount of Leaching Monomer from Poly Methyl Methacrylate Denture Base.. Al-Rafidain Dent J. 2009; 9(1): 94-104

Received: 3/1/2008 Sent to Referees: 3/1/2007

Accepted for Publication: 25/3/2008
\end{abstract}

\section{INTRODUCTION}

Acrylic resin is the most commonly used material for denture base, according to polymerization mode, acrylic resin may be classified as: Heat-polymerized, auto polymerized, microwave polymerized and visible light cured. Polymerization takes place as the free radicals open the double bond of the methyl methacrylate, creating a chain reaction where a monomer attaches to polymer free radicals, the degree of monomer conversion of resin materials is a measure of the carbon double bonds, into carbon single bonds. ${ }^{(1,2)}$

Free radicals polymerization can be inhibited by the presence of any substance that reacts with free radicals like oxygen, which inhibit or retard polymerization. ${ }^{(3,4)}$

One of the limiting uses of acrylic resin materials, is their biocompatibility. The methyl methacrylate monomer has been implicated as a primary irritant that can cause allergic reactions on the oral cavity. Although cold cured acrylic resin has been recognized as a tissue irritant; Heat polymerized denture resin may leach residual monomer into saliva and cause allergic reaction adjacent to denture. ${ }^{(4,5)}$ Thus a person can be sensitive to a denture base when heat cured has been incorrectly processed. ${ }^{(6,7)}$

Incomplete polymerization can also cause adverse effects on the mechanical 
properties and structural integrity of the resin by plasticizing effect which effectively reduces inter-chain forces causing deformation of the denture during use and storage. ${ }^{8}$, $9,10)$ The amount of residual monomer resent is dependent on the type of denture base resin, type of polymerization reaction, duration of polymerization and thickness of the denture base. . $^{(2,6,11,12)}$

Several methods for reducing the residual monomer contents and consequently the cytotoxicity of the denture base resin have been described. Preleaching in water was preferred by some investigations to reduce the subsequent leaching of methyl methacrylate, others stated that raising the polymerization temperature or post polymerization microwaving and additional soft liner polymerization can increase the degree of conversion of unreacted monomer. ${ }^{(13,15,16)}$

It is reasonable to imply that the post polymerization treatment could produce favorable results. ${ }^{(14)}$ Applying a poly methyl methacrylate monomer / polymer slurry (monopoly syrup) could be helpful to seal the porous surface of the denture base material, since the monomer which is held in a porous structure can exert an adverse clinical effect on mucosa without being removed from the palate. ${ }^{(12)}$ This coating presented beneficial effects when used as a glazing for the denture base material and reduce removal of components to or from acrylic based soft liners preserving their surface integrity. ${ }^{(17-19)}$

There was a worldwide therapeutic use of plant- derived essential oils to promote physical well being, such oils are olive and grape seeds oils; which are well tolerated by oral mucosa in treating ulcers, gingivitis and supporting body during illness, especially grape oil "because the nutrient content of grape is close to that of blood plasma". (20-22) The use of these oils to paint the denture base could play a role in lowering the level of leached monomer.

Based on the current literature, the aims of this study was to evaluate the effect of : Monopoly, olive oil and grape seeds oil coatings, on the amount of residual methyl methacrylate monomer, that eluted from the heat-polymerized acrylic resin denture base materials.

\section{MATERIALS AND METHODS}

\section{tion:}

- Denture Base Specimens Prepara-

Twenty specimens of one brand of heat-cured acrylic resin denture base (Major base 2, Major prodotti Dentari, SPA, Italy), were prepared by using stone moulds in metal denture flasks, at dimensions of $(30 \mathrm{x}$ $10 \times 1.5 \mathrm{~mm}$ length, width and thickness respectively).

According to manufacture's instructions, a mixture of 3:1 parts powder to liquid was left to reach the dough phase at room temperature. After filling the moulds fully with the dough acrylic resin, the flasks were fitted and maintained under compression until the metal edges of the flask closed together in a hydraulic bench press for $15 \mathrm{mi}-$ nutes.

Curing was accomplished in a thermostatically controlled water bath at $70^{\circ} \mathrm{C}$ for 30 minutes, then processed at $100^{\circ} \mathrm{C}$ for an other 30 minutes. After deflasking, specimens were removed and excess material was cut away.

\section{- Coating Materials Preparation and Application:}

Three coating materials were used in this study, two of them were plant extracted oils: Grape seeds oil (Vitis vinifera) and olive oil (Oleum olivae), the other coating is a syruplike mixture of a semiset methyl methacrylate resin named: Monopoly, which was prepared by mixing heat-cured clear methyl methacrylate powder with auto polymerizing clear methyl methacrylate liquid, the mixture was composed of one part powder to ten parts liquid. The powder and liquid were placed together in a glass beaker at $130^{\circ} \mathrm{F}$ water bath and stirred for $8-10$ minutes until the mixture starts to thicken. ${ }^{(23)}$. Before applying the grape seeds and olive oils, they underwent: Betten droffs test for toxicity; in which negative results (no change in color) were obtained, indicated that these oils were safe and not toxic. ${ }^{(24)}$ Acrylic resin specimens were divided into four groups, each 
having 5 specimens, which were: Control group (the specimens left uncoated); Grape seed and olive oils coated groups, the specimens of each oil group were immersed into their corresponding oil container for 48 hour and washed thoroughly with distilled water, then dried before testing the residual monomer; the fourth group was coated with monopoly sealer, that was applied on the whole surface of the specimen with a smooth brush and allowed to dry for 4-5 minutes under 60-Watt lamp held approximately 2 inches from the surface of specimen. This procedure is repeated until three coats have been placed and dried. ${ }^{(23)}$

\section{- Monomer Release Test:}

Each specimens of each group was stored in a sealed glass container which contained $10 \mathrm{ml}$ of distilled water at $37^{\circ} \mathrm{C}$ at time intervals $\left(24,48\right.$ hours, $3^{\text {rd }}, 4^{\text {th }}, 5^{\text {th }}, 6^{\text {th }}$ and $7^{\text {th }}$ days). At end of each leaching period, the supernatants were removed and replaced daily by other $10 \mathrm{ml}$ of fresh distilled water.
The time dependence of the monomer concentration was followed by monitoring the amount of monomer present in the supernatant medium using: CECIL 2000 / Ultraviolet - visible spectrophotometer $(\lambda=$ $254 \mathrm{~nm}$ ) every 24 hour, during the analytical period. ${ }^{(25)}$

A liner calibration curve of methyl methacrylate (MMA) concentration as a function of absorbency at $254 \mathrm{~nm}$, was obtained using MMA standard aqueous solutions in the range of $0.1-1.2 \mathrm{~g} / \mathrm{dl}$.Figure( 1)

The results were expressed as a percentage of released residual monomer mass with respect to the weight of specimen. ${ }^{(25)}$

- Statistical Analysis:

Data were analyzed by using: One-way analysis of variance (ANOVA), performed at significances $P \leq 0.05$; with mean values that compared by Duncan Multiple Rang Test.

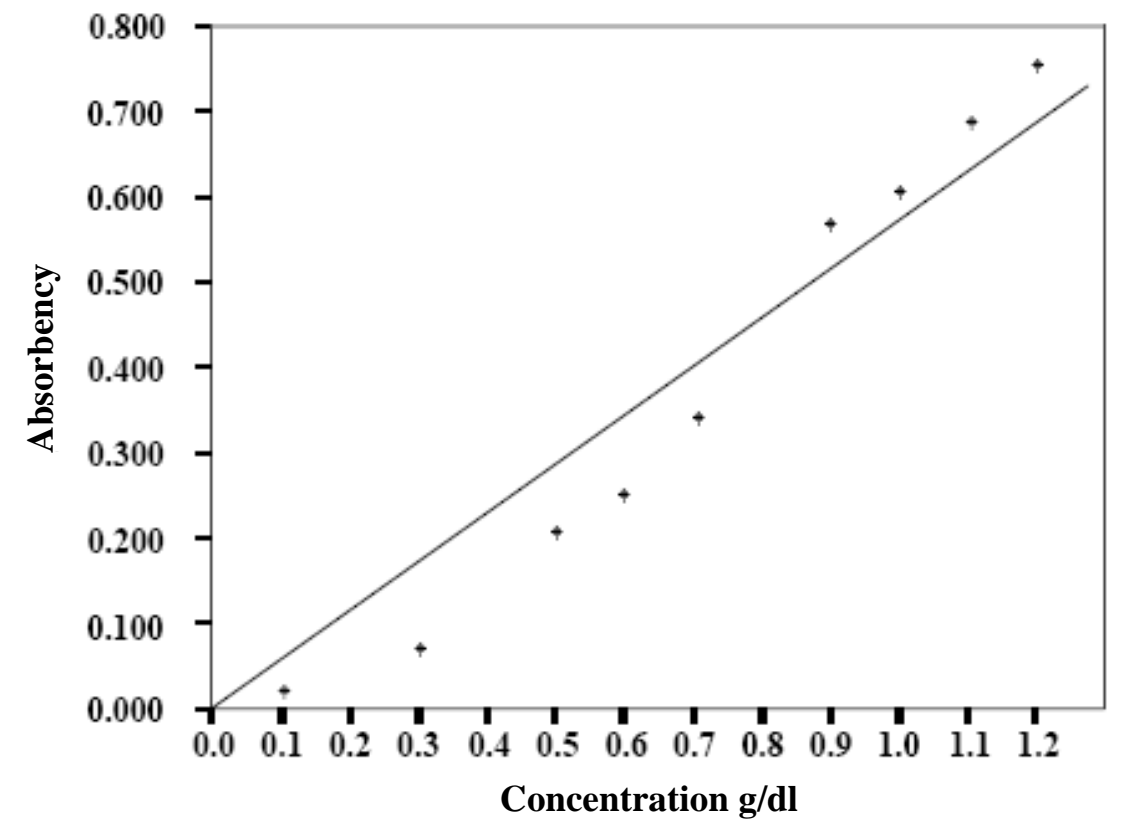

Figure (1): A calibration Curve of methyl methacrylate (MMA) Concentration as A Function of Absorbency 


\section{RESULTS}

The Results of monomer released for each experimental group at various time intervals were analyzed by: One-way Analysis of Variance (ANOVA) at $P \leq 0.05$. Table (1), showed that there was a significant dif- ference in residual monomer percentage in the uncoated (control) and with the monopoly coated groups, but there was insignificant difference in groups coated with grape seeds and olive oils.

Table (1): One-Way Analysis of Variance (ANOVA) for the Residual Monomer's (RM) percentage, of experimental groups during test period.

\begin{tabular}{llccccr}
\hline & $\begin{array}{c}\text { Groups } \\
\text { of experiment }\end{array}$ & Sum of Square & df & Mean Square & F & Significances \\
\hline \multirow{2}{*}{ G1 } & Between Groups & 0.171 & 6 & 0.028 & 6.234 & 0,000 \\
& Within Groups & 0.128 & 28 & 0.005 & & \\
& Total & 0.298 & 34 & & & \\
\hline \multirow{2}{*}{ G2 } & Between Groups & 0.208 & 6 & 0.035 & 10.274 & 0.000 \\
Within Groups & 0.094 & 28 & 0,003 & & \\
& Total & 0.302 & 34 & & & \\
\hline \multirow{2}{*}{ G3 } & Between Groups & 0.019 & 6 & 0.003 & 0.821 & 0.563 \\
& Within Groups & 0.108 & 28 & 0.004 & & \\
\hline \multirow{2}{*}{ Gotal } & Between Groups & 0.126 & 34 & & & \\
Within Groups & 0.003 & 6 & 0.000 & 0.915 & 0.499 \\
& Total & 0.017 & 28 & 0.001 & & \\
\hline
\end{tabular}

G1: Control group; G2: Coated with monopoly coating; G3: Coated with Grape oil; G4: Coated with Olive oil; df: degree of freedom.

Duncan's Multiple Range Test with Figures (2-5): showed that leaching of residual monomer was higher at the first 48 hours for the control group, and in the first 24 hours for the monopoly and grape seeds oil coated groups; while the higher values of residual monomer leached recorded in olive oil coated group at the first three days, as a percentage; then the leaching of residual monomer declined till the seventh day of experiment, which had the lowest mean values for the all studied groups

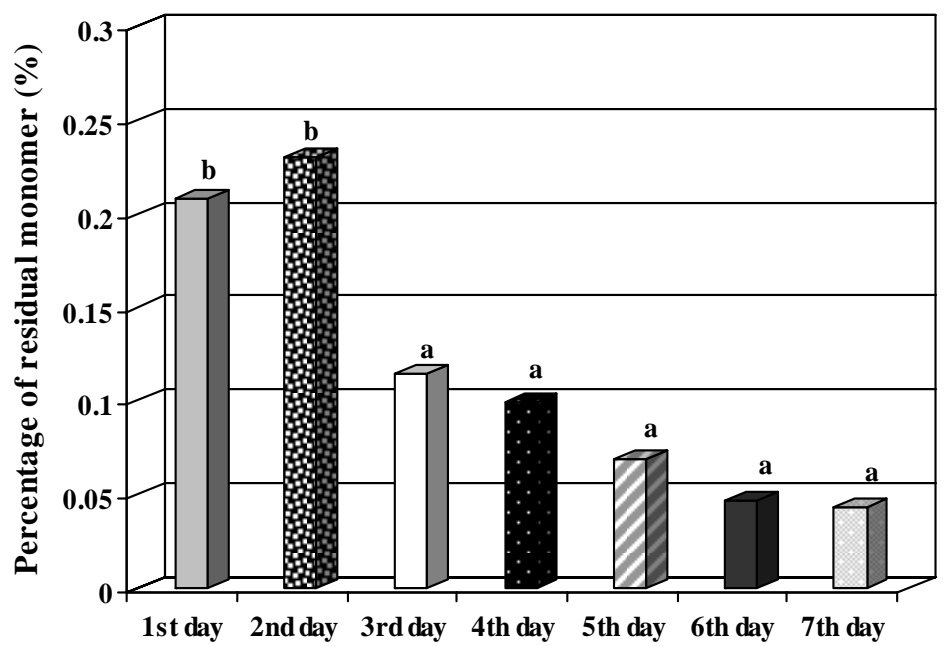

Figure (2): Duncan Multiple Rang Test of the Residual Monomer's (RM) Percentage, for the Control Group 
The Effect of Some Coatings on Leached Monomer.

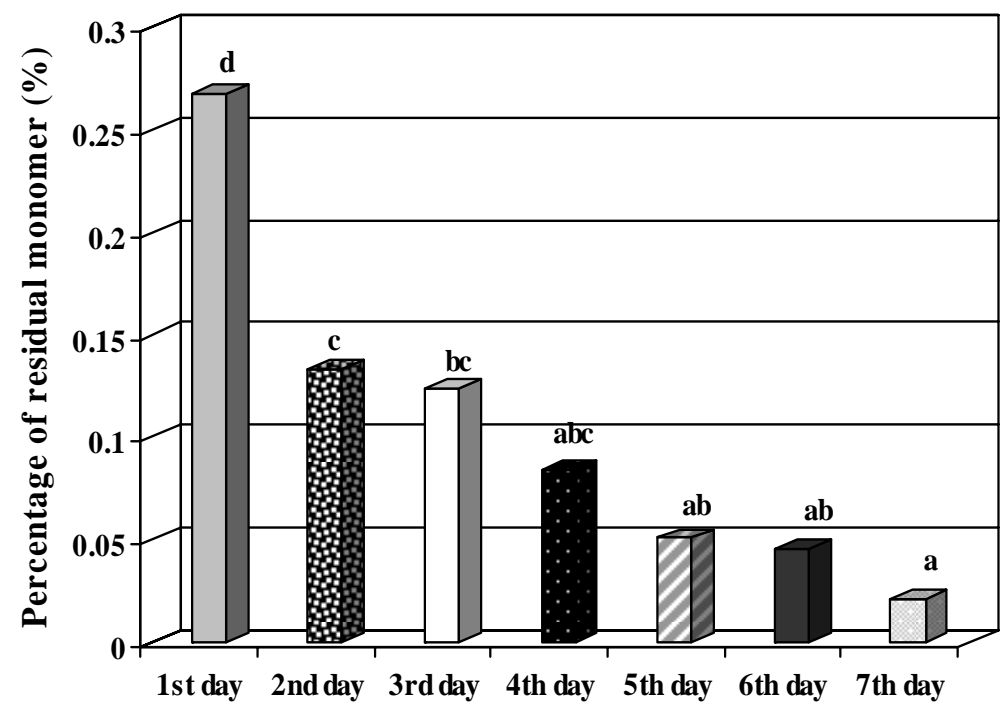

Figure (3): Duncan Multiple Rang Test of the Residual Monomer's (RM) Percentage, for the Monopoly Coated Group

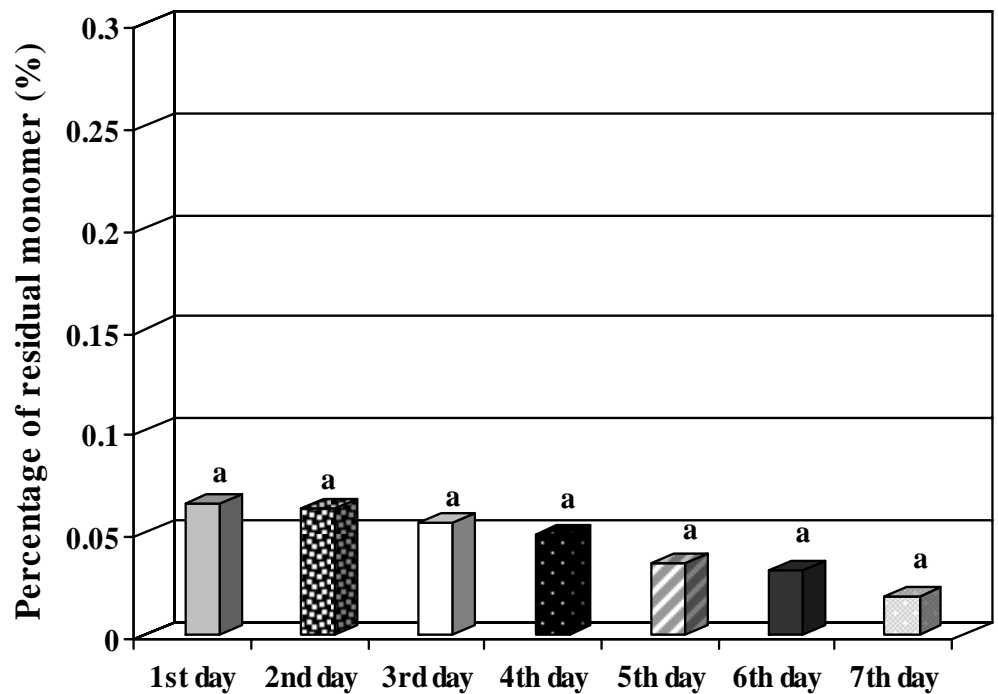

Figure (4): Duncan Multiple Rang Test of the Residual Monomer's (RM) Percentage, for the Grape Oil Coated Group 


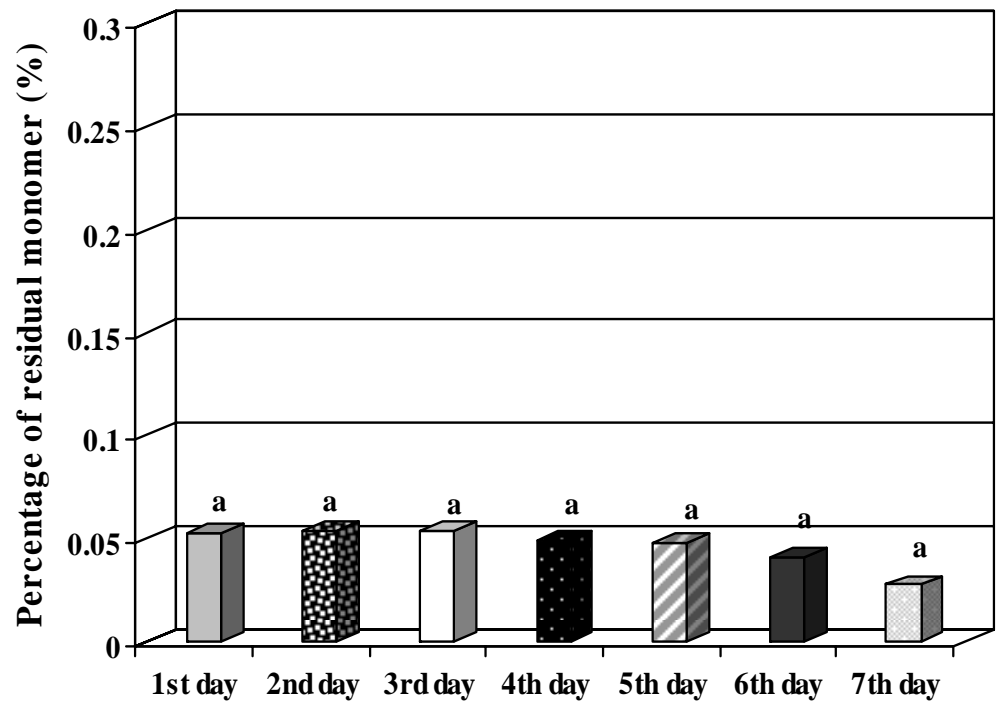

Figure (5): Duncan Multiple Rang Test of the Residual Monomer's (RM) Percentage, for the Olive Oil Coated Group

There was a significant difference in residual monomer percentage among the experimental groups at the first and second days, but no significances was observed from the third till the seventh days, Tables (2 and 3). Data analysis also showed that during all the experimental period, the monomer percentage released by day into unionized water was lowest with grape and olive oils coated groups, in comparison to control and monopoly coated groups.

ANOVA at Table (4) and Duncan's Multiple Range Test with Figure (6) showed, a different reduction in the residual monomer percentage; it was highest in monopoly coated group (-0.0411), followed by the control group $(-0.0275)$; then lowest in grape seeds and olive oils coated groups (0.0077 and -0.0042 ), respectively; i.e. the monopoly coated group showed a sharp and sudden reduction in monomer leaching daily. While the oils coated groups observed a gradual reduction.

\section{DISCUSSION}

From a biological perspective, the released methyl methacrylate and it's derivatives from the denture base resins have been reported to possibly induce a certain reaction and hypersensitivity of the oral mucosa in the range of their leaching concentration. Residual monomer contents varies with the methods and conditions of polymerizations, while the effect on oral mucosa is affected by the condition of the oral tissues. It is possible that youthful mucosa possesses higher resistance to chemical irritation than aged one, and the direct contact of the monomer with impaired tissue should induce a higher cytotoxicity than with normal tissue. Furthermore, the quality and quantity of a youth ful saliva serves to mitigate the effect of monomer. ${ }^{(3,12,26)}$

There has been a continual search for reduction of unreacted methyl methacrylate monomer, in this study the using of some coating materials (monopoly, grape and olive oils) to seal the outer surface of acrylic resin denture base specimens was performed.

Results of this study, showed that regardless the type of the group, residual monomer contents detected in the $1^{\text {st }}$ two days of analysis, were higher than those detected in the subsequent days, then decreased with time. The decrease in the daily release of the monomer occurred as a result of the diffusion of the monomer into water and by continuous polymerization promoted by the active radicals found in the polymer chain, these results were supplied also by: Bartoloni, Del Bel Cry, De Olivera and others. ${ }^{(2,27,28)}$ 
Table (2): One-Way Analysis of Variance (ANOVA) for the Residual Monomer's (RM) percentage, between the tested groups at each day of experiment.

\begin{tabular}{|c|c|c|c|c|c|c|}
\hline & $\begin{array}{c}\text { Days } \\
\text { onsequences }\end{array}$ & $\begin{array}{l}\text { Sum of } \\
\text { Square }\end{array}$ & df & $\begin{array}{c}\text { Mean } \\
\text { Square }\end{array}$ & $\mathbf{F}$ & Significances \\
\hline & Between Groups & 0.170 & 3 & 0.057 & 26.461 & 0,000 \\
\hline Day 1 & Within Groups & 0.034 & 16 & 0.002 & & \\
\hline & Total & 0.204 & 19 & & & \\
\hline & Between Groups & 0.100 & 3 & 0.033 & 28.228 & 0.000 \\
\hline Day 2 & Within Groups & 0.019 & 16 & 0.001 & & \\
\hline & Total & 0.119 & 19 & & & \\
\hline & Between Groups & 0.021 & 3 & 0.007 & 0.909 & 0.458 \\
\hline Day 3 & Within Groups & 0.121 & 16 & 0.008 & & \\
\hline & Total & 0.142 & 19 & & & \\
\hline & Between Groups & 0.009 & 3 & 0.003 & 0.911 & 0.458 \\
\hline Day 4 & Within Groups & 0.054 & 16 & 0.003 & & \\
\hline & Total & 0.063 & 19 & & & \\
\hline & Between Groups & 0.003 & 3 & 0.001 & 1.067 & 0.391 \\
\hline Day 5 & Within Groups & 0.015 & 16 & 0.001 & & \\
\hline & Total & 0.018 & 19 & & & \\
\hline & Between Groups & 0.011 & 3 & 0.004 & 0.619 & 0.613 \\
\hline Day 6 & Within Groups & 0.095 & 16 & 0.006 & & \\
\hline & Total & 0.106 & 19 & & & \\
\hline & Between Groups & 0.002 & 3 & 0.001 & 1.714 & 0.204 \\
\hline Day 7 & Within Groups & 0.006 & 16 & 0.000 & & \\
\hline & Total & 0.008 & 19 & & & \\
\hline
\end{tabular}

df: Degree of freedom 
Table (3): Duncan Multiple Rang Test for the Residual Monomer's (RM) Percentage, at each day of experiment; between the tested groups .

\begin{tabular}{|c|c|c|c|}
\hline $\begin{array}{c}\text { Days of } \\
\text { Experiment }\end{array}$ & Coating Group & Mean \pm Sd \% (w/w) & $\begin{array}{c}\text { Duncan's } \\
\text { Group }\end{array}$ \\
\hline \multirow{4}{*}{$1^{\text {st }}$ day } & Control group & $0.2084 \pm 0.02611$ & $\mathrm{~b}$ \\
\hline & Monopoly group & $0.2680 \pm 0.07602$ & $\mathrm{~b}$ \\
\hline & Grape oil group & $0.0648 \pm 0.03443$ & $\mathrm{a}$ \\
\hline & Olive oil group & $0.053 \pm 0.03029$ & $\mathrm{a}$ \\
\hline \multirow{4}{*}{$2^{\text {nd }}$ day } & Control group & $0.2304 \pm 0.03302$ & $\mathrm{c}$ \\
\hline & Monopoly group & $0.1340 \pm 0.05028$ & $\mathrm{~b}$ \\
\hline & Grape oil group & $0.0624 \pm 0.01892$ & $\mathrm{a}$ \\
\hline & Olive oil group & $0.0542 \pm 0.02744$ & $\mathrm{a}$ \\
\hline \multirow{4}{*}{$3^{\mathrm{dr}}$ day } & Control group & $0.1144 \pm 0.14299$ & $\mathrm{a}$ \\
\hline & Monopoly group & $0.1240 \pm 0.09562$ & $\mathrm{a}$ \\
\hline & Grape oil group & $0.0558 \pm 0.01630$ & $\mathrm{a}$ \\
\hline & Olive oil group & $0.0546 \pm 0.02259$ & $\mathrm{a}$ \\
\hline \multirow{4}{*}{$4^{\text {th }}$ day } & Control group & $0.0992 \pm 0.08562$ & $\mathrm{a}$ \\
\hline & Monopoly group & $0.844 \pm 0.07373$ & $\mathrm{a}$ \\
\hline & Grape oil group & $0.0508 \pm 0.01982$ & $\mathrm{a}$ \\
\hline & Olive oil group & $0.0497 \pm 0.01616$ & $\mathrm{a}$ \\
\hline \multirow{4}{*}{$5^{\text {th }}$ day } & Control group & $0.0698 \pm 0.04437$ & $\mathrm{a}$ \\
\hline & Monopoly group & $0.0512 \pm 0.01406$ & $\mathrm{a}$ \\
\hline & Grape oil group & $0.0358 \pm 0.03707$ & $\mathrm{a}$ \\
\hline & Olive oil group & $0.0488 \pm 0.01169$ & $\mathrm{a}$ \\
\hline \multirow{4}{*}{$6^{\text {th }}$ day } & Control group & $0.0466 \pm 0.00658$ & $\mathrm{a}$ \\
\hline & Monopoly group & $0.0464 \pm 0.01043$ & $\mathrm{a}$ \\
\hline & Grape oil group & $0.0320 \pm 0.15242$ & $\mathrm{a}$ \\
\hline & Olive oil group & $0.0414 \pm 0.01169$ & $\mathrm{a}$ \\
\hline \multirow{4}{*}{$7^{\text {th }}$ day } & Control group & $0.0434 \pm 0.01939$ & $\mathrm{a}$ \\
\hline & Monopoly group & $0.0214 \pm 0.01929$ & $\mathrm{a}$ \\
\hline & Grape oil group & $0.0185 \pm 0.00828$ & $\mathrm{a}$ \\
\hline & Olive oil group & $0.0278 \pm 0.02488$ & $\mathrm{a}$ \\
\hline
\end{tabular}

Table (4): One-Way Analysis of Variance (ANOVA) for the Effect of Coating Materials on the reduction difference of Residual Monomer (RM).

\begin{tabular}{lccccc}
\hline & $\begin{array}{c}\text { Sum of } \\
\text { Squares }\end{array}$ & Df & $\begin{array}{c}\text { Mean } \\
\text { Square }\end{array}$ & F & Significances \\
\hline Between Groups & 0.005 & 3 & 0.002 & 18.609 & 0.000 \\
Within Groups & 0.001 & 16 & 0.000 & & \\
Total & 0.006 & 19 & & & \\
\hline
\end{tabular}

df: Degree of freedom 


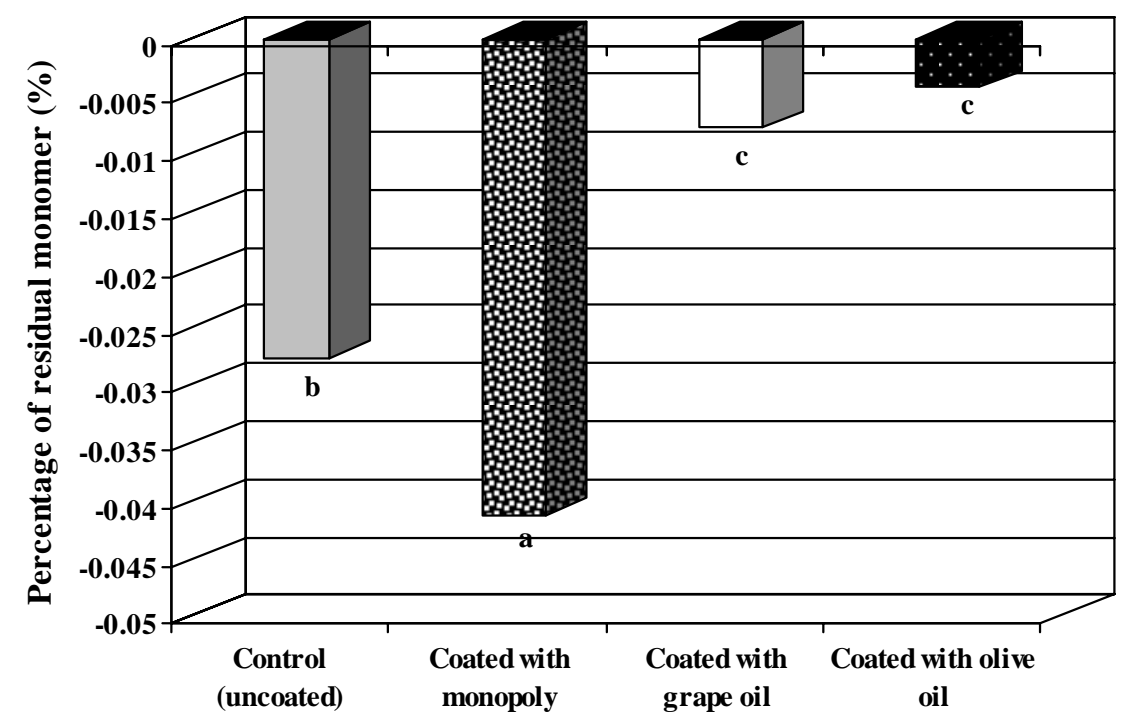

Figure (5): Duncan Multiple Rang Test for the Effect of Experimental Coating Groups on Reduction Difference of Residual Monomer (RM) Releasing

G

rape seeds and olive oils are used in curative purposes and in preservation of food from bacteria. ${ }^{(29)}$ In this study, results showed a positive effect of these two oils in decreasing the amount of leaching monomer than other groups, this is probably because, these oils form a protecting layer around the surface of the denture base and causing a further polymerization of the unreacted monomer. Thus, these natural oils will observe a double action when used intraorally, besides the reduction of the monomer leaching from the denture base, they could be used in contact with impaired oral tissues; especially grape oil, as they increase the level of antioxidants in the body, which are substance that destroy free-radicals damaging components that alter cell membrane, tamper with DNA the genetic material; and even cause cell death. Antioxidants found in these oils can neutralize free radicals and may reduce or help preventing some of the damage that caused, with decreasing subsequent adverse effects. Antioxidants in these oils are: Vitamin E, Flavonoids, Olein, Linoleic acid, and Proanthocyanidins. ${ }^{(20-22)}$

The effect of monopoly coating on reduction of the residual monomer was lower than the effect of oils, and this reduction was sudden and sharp throughout the analytic period, but the higher percentage of leached residual monomer was observed with monopoly in the first day; this was not completely due to the unreacted monomer from the denture base, but also because the monopoly coating leaches unreacted monomer it self. $^{(18)}$

\section{CONCLUSSION}

Regardless of the groups, the residual monomer leaching decreased during the period of analysis. The use of olive oil was beneficial in reducing monomer leaching, followed by grape seeds oil although the difference was insignificant and both of these oils were more effective in reducing leached monomer than using monopoly coating, or when the denture base left uncoated. Finally, it is better to leave the denture immersed in water two days before insertion in the patient mouth, especially when the denture base resin is left uncoated.

\section{ACKNOWLEDGEMENTS}

The authors would like to acknowledge: Dr. Isam k. Al-Khayat, Amer A. 
Taqa, and Nahla Om. Tawfik; for their time and support to finish this research; and to whom, that gave their permission for the manuscript to be published.

\section{REFRENCES}

1. Sadamori S, Kotani H, Hamada T. The usage period of dentures and their residual monomer contents. J Prosthet Dent. 1992; 68: 374-376.

2. Bartoloni J, Murchison D, Wofford D, Sarkar N. Degree of conversion in denture base materials for varied polymerization techniques. J Oral Rehabil. 2000; 27: 488493.

3. Lee S, Lai Y, Hsu T. Influence of polymerization conditions on monomer elusion and microhardness of auto polymerized poly methyl methacrylate resin. Eur J Oral Sci. 2002; 110: 179-183.

4. Jorge J, Giampaolo E, Vergani C, Machado A. Cytotoxicity of denture base resins: Effect of water bath and microwave post polymerization heat treatments. Int $J$ Prosthet. 2004; 17(3): 340-344.

5. Jorge J, Giampaolo E, Vergani C, Machado A. Cytotoxicity of denture base resins: A literature review. J Prosthet Dent. 2003; 90: 190-193.

6. Kawaguchi M, Takahashi Y, Fukushima T, Habu T. Effect of light- exposure duration on the amount of leachable monomers from light-activated reline material. $J$ Prosthet Dent. 1996; 75(2): 183-187.

7. Jorge J, Giampaolo E, Vergani C, Machado A, Pavarina A, Carlos I. Biocompatibility of denture base acrylic resins evaluated in culture of L929 cells. Effect of polymerization cycle and post-polymerization treatments. Gerodontology. 2007; 24: 52-57.

8. Arab J, Newton J, Lioyd C. The effect of an elevated level of residual monomer on the whitening of a denture base and its physical properties. J Dent. 1989; 17(4): 189-194.

9. Sadamori S, Ganefiyanti T, Hamada T, Arima T. Influence of thickness and location on the residual monomer content of denture base cured by three processing methods. $J$ prosthet Dent. 1994; 72(1): 19-22.
10. Salem S, Al-Doori D. The effect of microwave polymerization on the level of residual monomer in acrylic resins. Iraqi Dent $J$. 1999; 24: 255-262.

11. McCabe J, Basker M. Tissue sensitivity to acrylic resin: A method of measuring the residual monomer content and its clinical application. Brit Dent J. 1976; 140: $347-$ 350 .

12. Austin A, Basker R. The level of residual monomer in acrylic denture base materials. Br Dent J. 1980; 149: 281-286.

13. Austin A, Basker R. Residual monomers levels in denture bases: The effect of varying short curing cycles. Br Dent J. 1982; 153: 424-426.

14. Tsuchiya H, Hoshino Y, Tajima K, Takagi $\mathrm{N}$. Leaching and cytotoxicity of formaldehyde and methyl methacrylate from acrylic resin denture base materials. $J$ Prosthet Dent. 1994; 71(6): 618-624.

15. Blagojevic V, Murphy V. Microwave Polymerization of denture base materials. A comparative study. J Oral Rehabil. 1999; 26: 804-808.

16. Shim J, Watts D. Residual monomer concentrations in denture-base acrylic resin after an additional, soft liner, heat-cure cycle. Dent Materials. 1999; 15: 296-300.

17. Taft R, Cameron S, Knudson R, Runyan D. The effect of primers and surface characteristics on the adhesion- in-peel force of silicon elastomers bonded to resin materials. $J$ Prosthet Dent. 1996; 76(5): 515-518.

18. Dominguez N, Thomas C, Gerzina $\mathrm{T}$. Tissue conditioners protected by a poly( methyl methacrylate) coating. Int $J$ Prosthodont. 1996; 9(2): 137-141.

19. Murata H, Narasaki Y, Hamada T, McCabe J. An alcohol-free tissue conditioner. A laboratory evaluation. J Dent. 2006; 34(4): 307-315.

20. Yamakoshi J, Saito M, Kataoka S. Safety evaluation of proanthocyanidin-rich extract from grape seeds. Food Chem Toxicol. 2002; 40(5): 599-607.

21. Faria A, Calhau C, De Freitas V. Procyanidins as antioxidants and tumor cell growth modulators. J Agric Food Chem. 2006; 54(6): 2392-2397. 
22. Busserolles J, Gueux E, Balasinska B. In vivo antioxidant activity of procyanidin-rich extracts from grape seed and pine (pins maritime) bark in rats. Int J Vitam Nutr Res. 2006; 76(1): 22-27.

23. Gardner L, Parr G. Extending the longevity of temporary soft liners with a mono-poly coating. J Prosthet Dent. 1988; 59(1): 7172.

24. Feigl F, Anger V. Spot Tests in Inorganic Analysis. $6^{\text {th }}$ ed., Elsevier publication Co., 1972; Pp: 500-501.

25. Azzarri M, Cortizo M, Alessandrini J. Effect of the curing conditions on the properties of an acrylic denture base resin microwave polymerized. J Dent. 2003; 31: 463-468.

26. Jorge J, Giampaolo E, Vergani C, Machado A, Pavarina A, Carlos I. Effect of post- polymerization heat treatments on the cytotoxicity of two denture base acrylic resin. $J$ Appl Oral Sci. 2006; 14(3): 203-207.

27. Del Bel Cury A, Rached R, Ganzarolli S. Microwave cured acrylic resins and silicongypsum molding technique. J Oral Rehabil. 2001; 28: 433-438.

28. De Oliveira V, Leon B, Del Bel Cury A, Consani S. Influence of number and position of flasks in the monomer release, knoop hardness and porosity of a microwave-cured acrylic resin. J Oral Rehabil. 2003; 30: 1104-1108.

29. Pretty I, Gallagher M, Martin M, Edgar W, Higham S. A study to assess the effects of a new detergent- free, olive oil formulation dentifrice in vitro and in vivo. $J$ Dent. 2003; 31(5): 327-332. 